\title{
God's Story and Bioethics: The Christian Witness to The Reconciled World
}

\author{
HANS G. ULRICH* \\ Friedrich-Alexander University, Erlangen-Nuremberg, Germany \\ *Address correspondence to: Hans. G. Ulrich, PhD, Friedrich-Alexander \\ Universität, Fachbereich Theologie, Kochstraße 6, 91054 Erlangen, Germany. \\ E-mail: hansg.ulrich@t-online.du.
}

In this article, I seek to put Engelhardt's work on Christian bioethics in the wider context. First, I discuss some fundamental issues inextricably linked to bis work: the difference and relation of a "secular world" to the Christian notion of the "world," the difference and relation between the concepts of "bistory" given with human "progress" appearing in the field of bioethics, in contrast to the Christian understanding of God's story with His "world." These issues will be discussed in connection with the philosophical work of Karl Löwith and Jürgen Habermas, among others. Next, I critically discuss Engelhardt's genealogical account of "modernity," in order to draw - with agreement-attention to this genealogy's implications for the Christian epistemology needed for a proper understanding of human nature (the conditio bumana). Discursive rational argument is not enough to secure a proper understanding of human nature, says Engelhardt. Yet, it will be shown that through the practice of Christian witness as a "good work"-which brings along with it different essential modes of understanding human nature-the Christian can encounter secular public discourse. I examine how the witness of a Christian ethos may contribute indispensable insights for public and secular discourse; this witness, I argue, implies radical consequences for medical research and treatment. Despite my general agreement with his work, one of my central theses will be that Engelhardt rests content too early in embracing an empty procedural account of the justice that can be achieved by the state. Christian witness can and ought to contribute more than this. ${ }^{1}$

Keywords: bioethics, biopolitics, Christian bioethics, common world, conditio bumana, epistemology, genealogy, good works, history-story, buman nature, judgment, justification, liberal state, modernity, morality, practical reason, public discourse, secularization, translation, understanding, witness 


\section{CHRISTIAN WITNESS WITHIN GOD'S STORY-AND THE "HISTORY" OF WESTERN CHRISTIANITY}

Bioethics, as it is widely discussed today, could hardly have been challenged more profoundly than in the work of H. Tristram Engelhardt, Jr. He not only offers many critical insights into the field but also presents a genealogical description of bioethics, in the light of which the dominant bioethical discourse of our day surfaces as one that contradicts the Christian tradition, along with its distinctive understanding of human nature, the conditio bumana. Engelhardt's work, I will argue, insofar as it concerns a message given within that Christian tradition, cannot be neglected if "ethics" and therefore also "bioethics" is to be involved in that tradition. Engelhardt identifies this Christian message as a call to conversion, as Gerald McKenny has emphasized (McKenny and Cherry, 2010, 110), ${ }^{2}$ a conversion to the original Christian faith, which includes a content-full morality. Engelhardt's presentation of that message is embedded in a reconstructed genealogy of Christianity from the perspective of a true Christian worship, grounded in God's story with us, human beings (as it is celebrated in Christian worship), and remaining within that story. The following considerations pose the question about the implications of this message and of Christian worship for "bioethics" in order to show the critical and epistemic contribution of that Christian tradition. The public and secular discourse of bioethics cannot neglect any insight from whatever religious tradition, if it is interested in an understanding of the conditio bumana not restricted to certain strategies of (rational) reconstruction $^{3}$ or moral determination. It can be seen, then, that there are some fundamental insights inextricably and exclusively linked with the Christian ${ }^{4}$ tradition. These insights have to be witnessed to the universal community of discourse, Christian or not.

There arise consequently questions within the wider context of pertinent discourse, as the discourse about "secularity" and "modernity." The following reflections try to illuminate this wider context in order to show how Christian bioethics as it is presented by Engelhardt is very much at the focus of that context and helps initiate a discussion about the revision of that context. ${ }^{5}$ The following reflections try to show to what extent the discussion about bioethics has to recognize that condition. They may be understood as a prolegomena for bioethical discourse as initiated and implemented by Engelhardt's work. Yet, in this critical engagement with Engelhardt's enterprise, my aim is both to point to questionable elements and to sharpen the contours of his work.

We will have to discuss how the "genealogical" method determines Engelhardt's message. The main question is how, or with what effects, this worship is a witness to the "world," given that Christians must address this world from the Christian perspective, even from the perspective of Christian worship. Has not this worship to be announced as a witness of a Christian 
"ethos," including a call to "good works" as the world (cosmos) is reconciled by God (within God's story), not in order to make a better world, depending on human power and techniques, but in order to address the witness of God's reconciled new world as it begins here and now? Is not witness that particular practice corresponding to the adventus of the kingdom, the practice of a grounded hope, communicating its unique understanding of the world and the conditio humana?

We may follow here John Howard Yoder's characterization of Christians' witness:

Even before the broken world can be made whole in the Second Coming, the witnesses to the first Coming - through the very fact that they proclaim Christ above the powers, the Son above the angels-are enabled to go on proleptically in the redemption of creation. Only this evangelical Christology can found a truly transformationist approach to culture. (Yoder, 1984, 61)

The question then is: in what respect the work of ethics, as it is realized in "bioethics" (including "practical reason"), belongs to this good work of witnessing to the "world." What does this "work" then imply_-given the fact that it relieves us from being bound to a general theory of "practical reason" conceived as replacement or equivalent for the story of God and its "grammar?" We try to follow here Paul's hopeful parenesis in Romans 12:2:

Do not be conformed to this world (aion), but be transformed by the renewing of your minds, so that you may discern what is the will of God-what is good and acceptable and perfect. (Rom 12:2)

The exploration of God's will is based on the final renewal of "understanding" (nous) and this understanding has to be witnessed to the "world." This good work of witness is part of the Christian worship, that is, of any Christian worship in the world and for the world within God's very own story with it.

The crucial question is how this Pauline disposition relates to Engelhardt's description of a Christian epistemology ${ }^{8}$ and his critical genealogical diagnosis of Western Christianity and its bondage to a rationalized world, as it appears significantly in a rational governance of "bios" and the corresponding phenomenon of "bioethics." We have to ask how the "renewal of understanding" and the exploration of "the good" according to God's will relates to Engelhardt's notion of a "noetic knowledge" - given Engelhardt's diagnosis that the problem with "bioethics" is about "epistemology." What about a specific noetic task of ethics as a "good work" grounded in God's story and addressed to the "world" in order to explore a different understanding of the conditio bumana, which provides orientation? This includes also the question for the implications of Engelhardt's presented genealogical "history" of Western Christianity and its "ethics." We have to ask Engelhardt: How does one articulate this "history" of Western Christianity within the context of God's story or within the critical perspective of this story? How 
does the Christian witness of God's story, which includes the reconciliation of the world (cosmos), relate to that genealogically reconstructed "history?" We will see whether the Christian witness is to be understood as the presence of good works addressed to the "world," including the good work of "ethics" and "bioethics" and its noetic task, not depending on or justified by that genealogically reconstructed "history," but in its very own logic following God's story with His people and with us human beings.

Thus, despite my general agreement with Engelhardt and my aim to both endorse and place his work in greater context, one of my central theses in this article will be that he rests content too early in his criticisms of modern liberal politics in embracing an empty procedural account of the justice that can be achieved by the state. Cannot insights and practical trajectories growing from the ethos of the witnessing community lend some ethical content to modern governance? I propose that this precisely is the "good work" of the Christian.

\section{GOD'S STORY, THE OTHER STORY, AND VARIOUS GENEALOGIES}

Engelhardt's discussion of bioethics refers to an elaborated "history," a genealogy that derives today's secular bioethics from an initially "Christian" bioethics, the "Christian" character of which, however, presented the result of a problematic or even catastrophic and fatal development. It was this development which led to the assumption that "Christian bioethics" could be replaced by an openly secular bioethics, an assumption, which, as Engelhardt's critique of that secular bioethics hopes to show, was false. This genealogical "history" sounds descriptive, invoking "facts" and delineating "processes" suggested as obvious. Yet Engelhardt's presentation presupposes the appropriateness of its analytical framework and of the way in which he uses concepts such as "secular," "world," "reason," and "culture," and others. All these concepts must be scrutinized for their adequacy." McKenny compares Engelhardt's genealogy with Hegel's "history" of reason: "Like Hegel, Engelhardt's argument traces the fate of reason in history to its culmination in immanence. But unlike Hegel, Engelhardt's narrative does not endorse this actualization of reason in history, and the moral content he seeks is not found in the immanent sphere of custom" (McKenny and Cherry, 2010, 109). Can we understand Engelhardt's positive perspective as one that is still bound to a (universal) Hegelian view of history, a view that looks toward a morally fully developed human community? Could we assume that Engelhardt, unlike Hegel, conceives that community as being equivalent to the "kingdom of God," yet realized as a "church," an ecclesial world fulfilling Christian hope-even if that world is placed under the conditions imposed by a given liberal state, as long as that state does not hinder Christians in maintaining their tradition? (Engelhardt, 1994b, 211-24). 
What is the Christian perspective on world history, what is its perspective on the "world?" This question also concerns the history of Christianity. In Engelhardt's work, world history may not have any meaning in and of itself. He seems to suggest that the ultimately unavoidable outcome of world history will be a liberal state allowing for unrestricted Christian worship (and at the same time safeguarding freedom of religion). In addition to considerations about "world," "history," and "Christianity" as a historical phenomenon, we then have to ask: what is the Christian hope about? This is the theological question, also indicated by McKenny's point. What is Christian hope about, if that hope must not be bound to the expectation of a different world or history-immanently or transcendently constituted-but if it is focused on God's story in Jesus Christ and on the continuation of this story within this "world" and its involvement in God's story? There is a paradigmatic difference between a (utopian) view of a different world (perhaps a morally fully developed world community) and the Christian hope for God's presence in continuation of His story. This difference corresponds to the distinction between philosophies of history, which have merely distant roots in Christian traditions, and a Christian eschatology of hope bound to God's story as it was confirmed in Jesus Christ and has been witnessed by Christians. So we will have on the one hand a discourse about "history" as it can be grasped and narrated by historiographical techniques, and on the other hand a Christian narrative following God's story with its very own critical relation to "history" and "world" and its practical implications.

Engelhardt's work draws attention to that specifically Western debate between philosophies of history and Christian eschatology as it relates to paradigmatically different approaches to Christian ethics, based on equally profound differences in (as he would call them) post-Christian and Christian epistemologies for understanding nature and human nature. Is there any epistemology for knowledge of and understanding about "nature" and human nature, the conditio bumana-perhaps a "rational" one, and therefore independent from the epistemology determined by the Christian witness story (and so not post-Christian)? Or is it the properly understood Christian story, insofar as it provides any morally relevant knowledge and understanding, also a rational one, in its very own logic? Engelhardt's genealogy of Western Christianity and its ethics denies the former and also affirms the latter. An epistemology, independent from the Christian ethos and its own rationality, appears deficient (cf. Habermas, 2003).

Engelhardt's narrative about the secularization of morality and its collapse (into fragmentation) differs from Josef Cardinal Ratzinger's, the later Pope Benedict XVI's, genealogical "history" of the Christian tradition (Benedict XVI, 2006). Ratzinger affirmed what he took to be a Greek tradition of seeing faith and reason as closely interrelated. He diagnosed several stages of de-Hellenization, that is, an ever-increasing differentiation between, or separation of faith and reason. In his view, this led to the confinement of 
the rational implications of faith to a separate domain of "practical reason," as affirmed by, and brought to prominence in the course of the development of Protestantism. Ratzinger's "history" also disagrees with philosophical genealogies, for example, the genealogy of Karl Löwith: Löwith distinguishes between Christian hope, as fundamental for the Christian tradition, and a "history" which he takes to be a result of a "secular" transformation of that Christian hope, where a reason was affirmed which left the Greek conception of a cosmic world (framing the Greek concept of reason) behind (Löwith, 1950). Ratzinger's narrative contradicts Löwith's categorical distinction between the Greek and the Christian grammar of an eschatological hope. Any concept of a meaningful "history" is, according to Löwith, the secular derivation of that Christian hope, lastly absorbing that hope and constituting the only context of reality and knowledge-and subjecting "nature" (instead of the Greek "cosmos") to rational understanding and reconstruction.

This account is relevant for a genealogy of bioethics as placed within the genealogy of Western Christianity itself, as Engelhardt has presented it. Löwith sees, in contrast with Ratzinger, nothing wrong with "modern" Christianity having distinguished and separated "history" and "nature." He does not address the problem (highlighted by Engelhardt) that "reason" is incapable fully to grasp the "natural" condition of life, and particularly of human life. He does not seem to realize that knowledge of nature and specifically human nature cannot be accomplished by the theoretical concepts of the unity of "nature" and "reason" in reflections about the human being as a per se rational being or in notions of a universal "incarnate reason" (cf. Dabrock, 2010 and Engelhardt, 2010).

This contrast between Löwith's and Engelhardt's account raises the most fundamental problem about "bioethics," that is, the problem of an adequate epistemology, not confined to normatively stated common criteria of scientific research. So the questions remain still open: What is the relationship between faith and reason? How can reason grasp and understand "nature," the "nature" of which we are part-so to say the whole cosmic reality?

Recent debates about radical genetic engineering bring into sharp focus the problem of whether reason can properly articulate the conditio bumana. In this connection, we read in Löwith:

To Augustine, man and universe were both contingent existences, but created by God. Though only man was created in the image of God, therefore surpassing the animal world, the uniform conception of creation nevertheless affects world and man alike. The Christian God, it is true, does not reveal Himself in the heavenly bodies or in a holy animal, but exclusively in mankind and thus in history. But Jesus Christ redeems not only fallen man but, with him, the whole of a fallen creation.

With the dissolution of these two ancient convictions-the classical and the Christian-historicism and existentialism came into being. If the universe is neither eternal and divine (Aristotle), nor contingent but created (Augustine), if man has 
no definite place in the hierarchy of an eternal or created cosmos, then, and only then, does man begin to "exist," ecstatically and historically. (Löwith, 1966, 28-9)

In these debates about how "human nature" is affected by techniques of reproduction and reconstruction, the problem arises, once again, of how to distinguish between "history" and "nature." Can we, as human beings, be understood within a "history" that is fundamentally determined by human achievements? How does such an understanding account for the genealogy of that "history" generated by human achievements in its distinction from some "nature" which may be considered as normative? The question of the "future of human nature" (Habermas, 2003) raised by the development of biosciences and medical techniques thus becomes salient for our understanding of "practical reason." ${ }^{10}$ In what sense can we talk in a moral sense about "human nature" and its "future" or about the conditio bumana within a historical dimension at all, and therefore also within a historical horizon of "practical reason?" This agenda about the "future of human nature" induces questions about human morality and its rational grounding insofar as "practical reason" is challenged to reflect elements of the conditio bumana which remain no longer (contingently) given because they become modified, and thus subjected to the historical circumstances framing that technology and its applications. This raises fundamental questions about the limits of morally licit interventions with human nature, and how these could be established on the basis of an ethics of "practical reason." So we read, for example, with Habermas:

The decoding of the human genome opens up the prospect of interventions that cast a peculiar light on a condition of our normative self-understanding, a condition that, although natural and thus far unthematized, now turns out nonetheless to be essential. (Habermas, 2003, 12-3)

The problem of the human genome places bioethics into focus for any reflection on "history," "nature," and "practical reason." The question is whether "bioethics" can remain within the confines of a "practical reason," even of a "renewed" practical (moral) reason that integrates the wider horizon of a genetically modified human nature, or whether "bioethics" must instead be embedded in an ethos - a transcendent Christian ethos- that offers guidance about both the "right" and the "good," while also preserving or even rescuing the human condition in all its dimensions, limits, and determinations, which otherwise would get lost.

Here we may listen to Engelhardt:

With the secularization of morality, a new gulf emerges between the ideals of moral action and the broken character of the world. The physical world is deaf to human suffering, and tragedy is unredeemed. The universe is suffused with suffering, human and animal. Death and suffering shatter the lives of individuals, spouses, parents, children, families, and communities. The physical world is unresponsive to 
the ideals of the right and the good. Ours is a cosmos that breaks projects, hopes, interests, and strivings. Worse yet, the struggle for survival, out of which all life is seen to have evolved, is characterized by suffering, death, and the frustration of the deepest yearnings of both humans and animals. Without the metaphysical force of Christian redemption, the world apart from God is unredeemed from non-moral as well as moral evil. After all, in the long run, without God all is obliterated. This unredeemed brokenness makes implausible striving at all costs for the right and the good, if this goes contrary to intimate bonds and sympathies. If nothing endures in the long run, why should one struggle courageously for the right and the good, especially in those circumstances when this will be at the expense of kith and kin? Without God and immortality, why should one sacrifice those whom one loves on behalf of abstract commitments to the right and the good?

Kant recognizes this difficulty. However, Kant only in part acknowledges the depth of the tension between morality and reality, which Christianity had healed in the face of the ancient world's pagan stoicism. In the shadow of the loss of the traditional Christian metaphysical perspective, the cosmos is manifestly deaf to the right and the good. Moral ideals that had been nurtured in the expectation of eternity are now placed in an indifferent if not hostile cosmos. In profound contrast, traditional Christianity recognizes that the broken character of the universe, rooted in the free choice of Adam and Eve, finds its restoration through the free choice of a second Eve and a second Adam. The second Eve submits and gives birth to the second Adam, Christ, who as God and man reconciles the cosmos with God, guaranteeing full reward for human moral striving.

So far the "history." Engelhardt continues:

All of morality and human history are embedded in a narrative defined both by human freedom and God's infinite power. Human choice and its consequences are real, including the free choices of the God-man Christ in conformity with the will of the Father and in the Holy Spirit. In this cosmic narrative in which God plays the cardinal role, the right and the good are in the end fully integrated, the various goods placed in concert, and the motivation for justified moral action secured (e.g., through eternal punishments and rewards). Tragedy is real, though redeemed. Against such expectations, secular morality is at best broken and incomplete. (Engelhardt, 2000, 79-80)

Here "history" and God's story within the Christian witness, the "cosmic" story that encompasses both the conditio bumana and also the task and horizon of practical reason (reflecting the right and the good in its unity) are interwoven. Only within this complex disposition can the philosophical and theological discussion about the rationality of morals and reflections on "faith and reason" be adequately addressed. The implied historical notion and genealogy of Western Christianity raises the fundamental question of a Christian understanding of the conditio bumana within and/or in contradiction to the conditional context of a specific Christian "history" and its narrative. Christians have to follow God's story which has been witnessed and has to be witnessed by Christians in their ethos and worship, and therefore the conditio bumana appears in a different way, it appears in that story, it appears "hidden" (Engelhardt: "embedded") in that story, ${ }^{11}$ not delivered to a 
history of secularization, its success or expiration (Habermas and Ratzinger, 2006).

So we have in Engelhardt's display a multifold interweaving of issues and approaches, but they are nevertheless quite pointedly focused. They are focused on the question of a conditio bumana, which cannot be definitely determined by human "choices," and they are focused on the question of whether "faith and reason" can really characterize the conditio bumana in terms of a morality genuinely given with it, instead of a Christian ethos preserving the conditio bumana, an ethos, which has to be addressed, witnessed, and practiced. So it is decisive in which way the-fatal- "history" together with all its secular-Christian perspectives encounters a different "story" and-within this story-a different understanding of the conditio bumana and the ethics of "practical reason" in its specific contours.

Engelhardt's "history" of Western Christianity can be read (with McKenny and Cherry, 2010) as a "genealogy," as Alasdair MacIntyre has characterized this genre in his account of Three Rival Versions of Moral Inquiry (1990). This "genealogy" of Christianity's decay-especially in the perspective of the development of bioethics - presents a moral inquiry, that is, an inquiry into the phenomenon of morality in our Western culture, where it has become a cosmopolitan morality. Genealogies seek to disclose constitutive elements of a "culture,"12 and morality may rank as the most dominant and determining element of any culture. One must discuss and compare various similar "genealogies," which show quite different notions of Christianity or fundamental elements of Christianity-for example, Charles Taylor's presentation of the Secular Age (2007) and Karl Löwith's theologically most pointed Meaning in History (1950) or Hans Joas's recently presented genealogies on the development of "values" and "human rights" (2001 and 2013). Each of these genealogies, just as in the case of Engelhardt, shows a particular outcome that was generated by Christian faith and thought. These genealogies set an alternative Christian tradition, which is not lost in all that transforming (secularizing) processes, but which has to be seen as the true Christian tradition. The question then remains which of these alternative traditions really proves not only to be comparatively closest to that "true" Christian tradition as Engelhardt claims for the tradition of "Orthodoxy," but which can be seen as the logic of a witnessed story - the kind of witness I put here as central—which otherwise would be obliterated.

A most significant approach to this fundamental issue can be seen in Friedrich Nietzsche's "history" of Christianity. This history-rightly understood-again stipulates some presumably true tradition which has been lost. In his Genealogy of Morals (1887), Friedrich Nietzsche analyzes the function and grammar of what he describes as the socially dominant morality. Morality in this genuine grammar, in Nietzsche's understanding, appears as the very core of Christendom. This grammar is about a specific obligation which Christians take to be imposed on all human beings. This obligation is taken 
to be grounded in "god" whose whole story, including the salvation achieved by Jesus Christ, is, as Nietzsche claims, about men's desire for "justification" before God, engraved into a "conscience," again a Christian invention. The "god" of this genealogy, we have to agree with Nietzsche, is not the "God" of the covenant with his people, and not "God" who has reconciled His world in Jesus Christ for His glory and His coming kingdom; it is a merely moral "god." The moral "god" is not God in His very own story with His creatures, but the justifying authority of morality (and truth) in its paradigmatic sense. Nietzsche is right in reminding us that Christian ethics should not be focused on moral justification. But how, then, does Christian ethics relate to "God?" Is there a different story with God and an equivalent ethos corresponding to that ethos as Engelhardt points to?

The moral "god," this justifying "god" is dead, as Nietzsche's Zarathustra proclaims. His dying did not result from disinterest, emancipation, or because of certain secular substitutes. This "god" was killed. He was not killed by radical critics and enlighteners like Nietzsche's Zarathustra. Rather, this moral "god," according to Nietzsche, was killed by the grammar of a "moral" obligation and justification, which generated the urge to stipulate "god's" existence, although this same grammar was from the very start destined to be eventually decoded and dissolved. The "genealogy of morals" discloses this dramatic process. The "moral" obligation was not bound to any specific "content" provided by God's own story with man, but on anything that was contingently considered "good" or "evil" and associated with that moral god. Nietzsche's genealogy provokes the question what any moral obligation should be focused on, if not on the desire for some kind of fundamental justification. So we have to see how the notion of justification is implied in any concept of practical reason and how this is then fundamentally affected by Nietzsche's critique. His attack affects any ethos or concept of practical reason which invokes a desire for discursive rational justification and meaning. Yet Nietzsche's critique seems to leave Engelhardt's account untouched.

Reformation Theology focused its critique of the then mainstream Christianity exactly on the issue of discursive rational justification. This theology sought not to affirm "god" as the source of justification and meaning over against other sources. This theology instead sought to replace the very grammar of "justification" (including primarily moral justification) by the grammar of God's merciful judgment and justice according to God's own story. The promise proclaimed by Reformation Theology is not justification or "meaning," but participation in God's justice. God's "justice” means (in keeping with biblical language) God's faithfulness to His people-they will not be delivered to other powers and also not to their own trespasses. God's justice guarantees that His story will continue. God's justice to His people is again realized in Jesus Christ. To believe in God means to participate in that justice. This logic, which notwithstanding has in many ways been misunderstood and corrupted, runs contrary to any grammar of human 
self-justification. Justification is granted by a living, present God, by "God in time," by God who governs human hearts by His Spirit and is present that way. Engelhardt's work provides very much the forum to explore this logic of Reformation Theology and to see how it proves as a critical guide for a Christian ethos in the field of "bioethics" and its contestation with its secular transformation. This includes, of course, the question whether Engelhardt's own critical approach given with his genealogical method is in any aspects in accordance with that logic as it touches fundamental issues concerning the substance of Christian ethics in its critical or contradictory relation to any other ethics. This proves that indeed, as Engelhardt suggests, bioethics is the paradigmatic field of that contestation.

\section{TWO APPROACHES TO A COMMON WORLD?}

Nietzsche's correct diagnosis about the death of the moral "god" does not imply that the problem of "moral" justification has disappeared. There always remains rational justification for actions insofar as they affect other people (cf. Forst, 2007). Any action has to be justified by reference to a common moral ground, which may be given with "practical reason" or by recognizing per se a common ground disclosed by reason, not by activities of "grounding" (cf. Hauerwas, 2001, 14-41). The practice of justification (by practical reason) is therefore to be seen, in its ethical contours, as focused on a peaceful living together, which can be neither guaranteed or enforced by the liberal "state" nor delivered to a permissive society or to a supposedly given morality of all participants within the human community. There is a rather explicit practice of justifying necessarily. This practice is not to be confined to a mere procedure without any content. It has to refer to a common reality, a common "world" generated or realized by this practice.

Within the perspective of the needed common "world" or context for a peaceful living together, the priority of the "right" over the "good" has been discussed (widely discussed by Rawls, also by Engelhardt). Included is the question why human beings need not only-within the grammar of practical reason-justification in order to live in peace together but also "truth," the true reality that implies what we may call a "good life" - that is, "good" according to a "world" beyond human evaluation, justification, and judgment, a "good life" constitutive for the conditio humana. Engelhardt's account raises the question of whether this "good life" can be sufficiently reflected on and articulated within the horizon-and limits-of practical reason.

Within the discourse about practical reason, it was held by Habermas and others that the "ethical" good or the "ethos" has to be seen in its indissoluble connection to moral justification-that is, within the context and the limits of practical reason. It is necessary to recognize an overlapping content of the "right" and the "good" within the inescapable sphere of the political living together. For this overlapping concordance, a full coincidence of "the right" 
and "the good" is not demanded, except with regard to such contents that are indispensable for a peaceful political coexistence. There is a demand for an ethic of practical reason, recognizing the need for justification and consensus according to certain indispensable content-full conditions of political coexistence. This common "world," thus enriched, is then not to be confined to a liberal "state." It has to be seen in contrast and even opposite to a mere permissive, and in this sense "peaceable" political community (Hauerwas, 1997, 31-44).

So we must obviously look at two distinct perspectives: the "moral" perspective of a peaceful living together-also (according to Habermas) within the contours of a content-full political ethos, including elements of the "good life" - and the appearance and recognition of a "good life" in all its dimensions-that is, an "ethos," which is in accordance with the exploration of "God's will, the good, the pleasant and the perfect" (Rom $12: 2$ ), and which has to be witnessed to the "world," even to that common "world" of a peaceful living together. Paul supposes obviously that "the good, the pleasant and the perfect," according to God's will, should become present in this world as a witness. It may be up to a philosophy, which is absolutely critical to any "history" providing a corresponding context, to doubt the realization of any "good life," as Adorno (1994) indicates in his famous judgment (Habermas, 2003, 1-15):13 "There is no right life (good life) in the wrong one." ${ }^{14}$ But, according to Paul, the ethos of a good life is just because of that lack of a still meaningful "history" or "world," a witness within this "world time."

Within the Christian ethos, the "good" life and "good works" appear as life and works within God's story, given with His creation and continued in His work of reconciliation. Any reflection on the "good" and its presence in the world refers to this story; there is no freestanding "good," no freestanding evaluation of "the good." God's commandments are again not a "freestanding" moral code. They are given to Israel not by a moral "god," but by the God Who has chosen Israel to be His people and who has continued this story with Jesus Christ.

As theories of justice challenged by the death of the moral "god" have to clarify the procedures and practices of justification within the contours of practical reason, Christians have to judge that there is no other "god" than the Father of Jesus Christ and the giver of the Law within the context of His story with His people and all human beings. Yet, we read in Habermas's essay on "The Future of Human Nature:"

The ethically conscious conduct of life should not be understood as narrow-minded self-empowerment. We could also agree with Kierkegaard that we should not understand this dependence on a power beyond our control in naturalistic terms, but above all as an interpersonal relation. For the defiance of a rebellious person who finally in despair wills to be herself is directed—as defiance-against a second person. Under the premises of post-metaphysical thinking, however, the power beyond 
us-on which we subjects capable of speech and action depend in our concern not to fail to lead worthwhile lives_cannot be identified with "God in time."

The linguistic turn permits a deflationary interpretation of the "wholly Other." As historical and social beings we find ourselves always already in a linguistically structured lifeworld. (Habermas, 2003, 10)

The replacement of Nietzsche's moral "god" by a "wholly Other," the logos of language, reflects God as interpersonal and not under men's control. The "God in time" (Gott in der Zeit), however, is (according to Habermas) also lost. Just this "God in time" was reminded in Löwith's reflection on Christian hope, committed to a story which is our story with God. The "wholly Other," in contrast, is still equivalent to Nietzsche's moral "god" in the grounding, justifying authoritative instance. This god is not the God who reigns over human hearts by His Spirit and continues that way His story with His people. So far, we are left with Engelhardt's diagnosis of the present situation:

Western Christianity promised a rational demonstration of the existence of God, as well as a universal morality generally disclosable by reason. Instead, discursive rational or speculative proofs for the existence of God run aground on the difficulty of inferring from the finite the existence of the infinite. . . Because of the fragmentation of Christian ethics, secular morality is invoked to secure what Western Christian morality promised: a coherent universal ethic. Secular thought is to supply a rationally justifiable, canonical, content-full morality that can reconcile the claims of the right and the good as well as bring into harmony the justification for morality and the motivation to be moral. As Kant understood, such a task can only be achieved by a morality that, among other things, can guarantee the congeniality of morality and reality. Secular morality has shown itself to be diverse, sundered, and unable to prevent profound tensions between the right and the good, between worthiness to be happy and happiness, between morality and reality. Secular morality cannot show that the morally righteous life will not, at least in some circumstances, be a miserable life, at least in this world. In a world that rewards cunning, not virtue, the price of living morally can be high. Finally, secular morality cannot deliver an unambiguously binding, unique, and rationally justified content for morality. (Engelhardt, 2000, 73)

On the part of Christen ethics, there is indeed the question of what its "promise" really is about-or what really characterizes the Christian ethos or a "content-full morality," and what then may follow for secular morality and its reflection of the conditio bumana. ${ }^{15}$

\section{HOW CHRISTIAN HOPE RELATES TO THE "WORLD” EVEN IN "MODERN" TIMES}

Christians, as we have noticed, are provoked by Nietzsche to forego the desire to be justified by discursive reasoning in their account of the good life and to get a justifying "meaning" for their life and, therefore, also a "meaning" of history to which they claim to belong. Löwith points to a Christian hope that "cannot rest on a rational calculation of their reasonableness." There is 
no meaning in history that could bear or provoke this hope. Christian hope is rooted in God's story and God's promise, to continue His story, and it is focused on the coming kingdom as it is promised and affirmed in Jesus Christ. It is hope for God's messianic adventus, according to God's story, and not bound to any kind of future. This is present in any Christian worship where Christians pray, "Thy kingdom come, Thy will be done." Christian hope contradicts any "hope" rooted in "history." The "god" of this "history" is dead, as is the moral "god," and has been killed in the same way.

Yet, we read again in Karl Löwith's Meaning of History:

We are neither ancient ancients nor ancient Christians, but moderns-that is, a more or less inconsistent compound of both traditions. The Greek historians wrote pragmatic history centered around a great political event; the Church Fathers developed from Hebrew prophecy and Christian eschatology a theology of history focused on the supra-historical events of creation, incarnation, and consummation; the moderns elaborate a philosophy of history by secularizing theological principles and applying them to an ever increasing number of empirical facts. It seems as if the two great conceptions of antiquity and Christianity, cyclic motion and eschatological direction, have exhausted the basic approaches to the understanding of history. (Löwith, 1950, 19)

Löwith's genealogy of a secularized notion of "history," which has missed the grammar of Christian hope, challenges Christians no less dramatically than Nietzsche's Genealogy of Morals and Engelhardt's genealogy of Western Christianity. Christians have to prove whether they really stick to their hope not depending on a history but embedded into God's story-from creation to consummation, grounded in God's promise and affirmation in Jesus Christ. Therefore, Christians cannot be "modern" in terms of an interpretation of "history" that provides the context of meaning and understanding. Löwith, however, discerns at once that we are not "ancient Christians" but still nolens volens, "moderns" pretending that we are able to provide a context of meaning within history. There seems, then, to be no way to real Christian "hope" - this would be, according to Löwith's historical perspective, looking backwards. We moderns appear determined by this "history" and its somehow perpetuated "meaning" - that is, the supposed progress to a better world, the secular way of a hope, originating in a Christian eschatology, but deprived of its very content and grammar. "Ancient" Christians in contrast, according to Löwith, would follow a different hope-not focused on a "better" world according to historical or any other human judgments or desires. Christians, within Nietzsche's critical perspective, would also not follow the logic of a universal morality, which is again, according to Engelhardt, a modern concept contradicting the Christian ethos embedded in God's story.

Is Christian hope in its relation to the present "world" obsolete, because "moderns" cannot forego at least a meaning in history and trust in progress and development, because they-whether they are Christian or not-need this kind of justification? Yet, there has to be seen an alternative between the 
modern "world," which is historically disposed that way, and a "world" which is beyond or independent from "secularization." According to this alternative, the modern "world" is still "secular" - that is, determined by Christian traditions and corresponding to them. This is the "world" of "Western Christianity," as Engelhardt describes it. This modern "world" has become now post-Christian secular, insofar as the Christian tradition does not even correlatively determine these times. The Christian notion of God's world and its story appear the more independent from (genealogically reconstructed) transformations of the "world." The Christian notion of God's world remains a witness to the "world," a witness which is present with the Christian worship and its implicit ethos. Although this notion is "ancient," as Löwith remarks, Christian witness is, as McKenny has seen Engelhardt's description of the real Christendom, "timeless." It is a timeless Christendom lost in modern Christian-secular or post-Christian secular times.

The question, then, is how this secular or post-secular "world" appears within the perspective of real Christian hope-that is, within the perspective of God's story Christians are part and witnesses of-and how the conditio bumana appears within the perspective of this hope. Dietrich Bonhoeffer has considered this as the very task of Christian ethics: to explore the "world" and its phenomena as they are definitely determined by the story of Jesus Christ. The "world" thus determined is the real world, the real reality. Its exploration following God's story includes any phenomena determined by this story - as first of all the phenomena of "death" and "dying," of "suffering," and all phenomena concerning human bodily life. How are these phenomena, constitutive for the conditio bumana, determined by the life and resurrection of Jesus Christ and the therein grounded hope for resurrection? How is medical care determined by this hope (Frewer, Bruns, and Rascher, 2010)? This is, within Bonhoeffer's logic, one of the leading questions within any ethical reflection on our dependence on medical care and its ethical appearance, also related to the ethos of physicians and medical professionals.

We read with Engelhardt:

Traditional Christianity provides bioethics a language out of step with a culture of self-determination and pride. It sees matters of suffering, dying, and death without a central focus on considerations of rights, dignity, and self-satisfaction. Instead, the focus is on how life in the body of Christ teaches us to live and die. At stake is a goal beyond freedom, dignity, and virtue: union with the transcendent God through taking on Christ's divinity, as He took on our humanity. The culture of traditional Christian belief focuses on life regained through the humiliation of death on the Cross. (Engelhardt, 2000, 332)

"Life regained through the humiliation of death on the Cross" - this is the story and a specific reference to it "taking on Christ's divinity," which contradicts the common grammar of human freedom, autonomy, dignity, etc. Ethical orientation is guided by a story definitely determining our world, a 
story going on-by God's justice-in present times, witnessed by Christian worship as it follows the biblical tradition.

\section{THE WITNESSED ETHOS AND ITS EXPLORATIVE UNDERSTANDING: THE GOOD WORK OF CHRISTIANS}

The distinction between a practical reason, justifying the acts and habits of people who have to live together, and a substantiated "ethos" witnessed to everybody cannot be separate, as critics have argued, insofar as practical reason must not be confined to abstract moral rules for living together, but must include judgments and discernments disclosing a common "world."16 A throughout content-full common "world" can be thought of, which still remains within the limits of practical reason. This presupposes, as Jürgen Habermas has argued, a "third standpoint" between an abstract universal practical reason and a particular substantiated and realized "ethos" (or what Habermas calls a "comprehensive worldview"). So we read in Habermas's discussion with Rawls:

The question is whether citizens can grasp something as reasonable if it is not open to them to adopt a third standpoint besides that of an observer or a participant. Can the plurality of reasons rooted in worldviews, whose nonpublic character is mutually recognized, lead to a consensus that can serve as the basis for a public use of reason for citizens of a political community? I wonder whether Rawls can account for the possibility of an overlapping consensus without tacitly assuming such a third perspective from which "we," the citizens, can publicly examine in common what is in the equal interest of everybody. (Habermas, 2011, 92-113, 101-2)

And we read again:

The concept of practical reason cannot be drained of moral substance and morality cannot be relegated to the black box of comprehensive doctrines. I cannot see any plausible alternative to the straightforward Kantian strategy. There seems to be no way around the explanation of the moral point of view in terms of a procedure that claims to be context-independent. Such a procedure is by no means free of normative implications, as Rawls correctly emphasizes [Rawls, 2011, 81], for it is intertwined with a concept of autonomy that integrates "reason" and "free will;" to that extent it cannot be normatively neutral. An autonomous will is one that is guided by practical reason. Freedom in general consists in the capacity to choose in accordance with maxims; but autonomy is the self-binding of the will by maxims we adopt on the basis of insight. Because it is mediated by reason, autonomy is not just one value alongside others. This explains why this normative content does not impair the neutrality of a procedure. A procedure that operationalizes the moral point of view of impartial judgment is neutral with respect to arbitrary constellations of values but not with respect to practical reason itself. (Habermas, 2011, 112)

This general issue is bound to the logic of "autonomy," yet not to the autonomy of isolated "individuals," but of moral persons, citizens, sharing not 
only abstract moral rules. Moral rules are also not on a "middle-ground" for compromises. They are situated in the political sphere of coexistence. From here arise significant questions concerning Engelhardt's account: How can Christians participate in this political sphere and contribute ethical implications from a different ethos? How can Christians relate their witnessed ethos to the political ethos of practical reason?

Josef Ratzinger, Pope Benedict XVI (who has been also in dialogue with Jürgen Habermas [Habermas and Ratzinger, 2006]) — as already mentionedhas presented in his speech, "Faith, Reason, and the University" (2006), an emphatic plea for an intercultural and interreligious dialogue, in distinction to a general (immediate) reference to "natural law" as a universal common ground for justification. This plea appears rooted in the confidence that the "truth" of Christian faith will be confirmed in its convergence with reason anyway (Engelhardt, 1994a, 235-45). So Ratzinger holds:

I would speak of a necessary relatedness between reason and faith and between reason and religion, which are called to purify and help one another. They need each other, and they must acknowledge this mutual need.

There can be no doubt that the two main partners in this mutual relatedness are the Christian faith and Western secular rationality; one can and must affirm this, without thereby succumbing to a false Eurocentrism. (Habermas and Ratzinger, 2006, 78-9)

This is different from Habermas's "third perspective," because Ratzinger presupposes the (encompassing) convergence of faith and reason on one side, the side of "faith and reason," and this is the side of Christian faith. Habermas in contrast is looking for a "discourse" by which an articulated common rational ground would be at stake, which finally remains not bound to "faith" in its world-encompassing range even if it is (necessarily) rooted in faith. Therefore, the practice of discourse-within that third perspective-appears as a quite limited, specific political practice, needed for a peaceful living together, peaceful according to an articulated peace, in particular as the "bond of peace" (Eph 4:3). This practical coexistence does not demand a morally fully developed political community and a corresponding ethics. Any comprehensive worldview, according to Habermas, may participate in this discourse for a limited purpose, without being confined to a "practical reason" overriding religious worldviews and its implicated morality. So it has to be reflected on by either side what is to be considered the most important contribution of Christian faith and ethos to that peaceful living together.

Engelhardt is aware of the need for that "third perspective," given a modern state and its inability to substitute a morally united community. So Engelhardt holds:

The state . . cannot provide a content-full morality in which all can share. It provides instead a public thing, a res publica, through which common resources can be employed and individuals protected. The guiding thread is not a content-full secular morality, but a process that acts with common authority. The result is a secular 
state tolerant in principle because of the limits of secular morality and secular moral authority. (Engelhardt, 1994b, 241)

But why should "the state" "provide a 'content-full morality' in which all can share"? This is to be expected only on the presupposition of that Hegelian secularized Christian perspective of a realized "kingdom of God" in history, where state, community, morality, and reason coincide within the institution of law. But we should ask with respect to Habermas: Why could not the res publica nevertheless be partly "content-full" even if this content is limited to what is needed for a peaceful political coexistence?

The very question is, moreover, how the limits of practical reason providing the res publica are not only negatively defined but positively by that witness of a Christian ethos. From here, then, it had to be seen how this ethos could nevertheless contribute to the res publica as far as it is articulated as determinedly corresponding to the context of practical reason. Christians, according to that perspective, would participate in a practice of cooperation for the res publica as a "good work," limited as it is, a good work of establishing a "bond of peace" (Eph 4:3) consisting of articulated substantial elements of "good life." They would not only affirm an empty peace but support a throughout ethically substantial peaceful living together. ${ }^{17}$ This cannot and must not imply accommodating Christian truth to a different logic, but will remain the witness of Christian faith indicating a throughout different common "world." Engelhardt rests content too early in his criticisms of modern liberal politics in embracing an empty procedural account of the justice that can be achieved by the state. The insights and practical trajectories growing from the ethos of the witnessing community can indeed lend some ethical content to modern governance. This is the work of Christian witness.

There are obvious examples for those witnessed elements. There is anyway still an articulated language and praxis contradicting "euthanasia," "reproductive cloning," "eugenics," and many other ideas touching harmfully the conditio bumana and any corresponding ethos. How would a peaceful living together be possible, if there is no articulated consensus that nobody should get into a situation where it may be open what happens with regard to those moments of the conditio bumana? Would, for example, "cloning" - as Habermas argues-subvert the presupposed consensus that human beings are categorically equal because they are of absolutely equal origin? There cannot be human "creators" of human beings. Otherwise, the categorical equality of all human beings would be dissolved. This equality presupposes the distinction between "the Creator" and all human beings (Kampowski, 2013, 156-7). To maintain such elements of a really human "ethos" and its grammar is essential for any civic society - and it is obvious that this needs the witness of people who are involved in that ethos. 
This understanding of an explicitly performed and witnessed ethos is equivalent to a timeless "good work" not depending on any de facto given conditions or historical constellations. Engelhardt himself describes in Foundations of Christian Bioethics "good works" within medical care. We read, for example:

Instead, we must recognize with the Christians of the first centuries that we must care for pregnant women who need support, adopt children who would otherwise be killed, provide care for the dying such that self-murder does not become a temptation, and lovingly pray for those who murder. (Engelhardt, 2000, 395)

There are innumerable well-determined "good works" of this kind demanded and realized within medical care, also by professionals who are committed to an equivalent medical ethos-an ethos that is exclusively focused on therapeutic tasks and open to an ethically reflected notion of "therapy." This is similar to the area of economics where we find again innumerable "good works" on various levels, alternative practices of entrepreneurship. ${ }^{18}$ To do "good works" must not presuppose that the grammar of the common language would be changed, although it may not be excluded (why should it) that "good works" make a substantial difference for the appearance of medical care in a civic society.

"Good works" witness a logos, a word addressed to this "world." "Good works" are part of Christian hope, timeless. So we read in Ephesians 2:10: "For we are what he has made us, created in Christ Jesus for good works, which God prepared beforehand to be our way of life." This way of life belongs to the new "citizens of the saints" and the "members of the household of God" (Eph 2:19). Peace, then, is not substantiated by a permissive society or a liberal state, but it has to be substantiated by "good works." "Good works" do not necessarily imply the unity of "the right" and "the good," but "good works" addressed to others-and not (only) rationally mediated-may represent or substitute "the right."

\section{TRANSLATION}

This disposition is different to Habermas's point of a third perspective and a corresponding common practice since this practice requires-as he explicitly emphasizes - the "translation" of relevant contents with respect to a contentfull civic living together, also of religious contents, contents of "comprehensive worldviews," into common public notions and their ratio. Habermas presupposes that these contents are translatable without losing its very meaning, although their semantic content may not be exhausted by this translation.

What, then, does translation mean? Habermas himself warns:

Secular languages which only eliminate the substance once intended leave irritations. When sin was converted to culpability, and the breaking of divine commands to an offense against human laws, something was lost. The wish for forgiveness is 
still bound up with the unsentimental wish to undo the harm inflicted on others. (Habermas, 2003, 110)

And then Habermas holds:

When secularized citizens act in their role as citizens of the state, they must not deny in principle that religious images of the world have the potential to express truth. Nor must they refuse their believing fellow citizens the right to make contributions in a religious language to public debates. Indeed, a liberal political culture can expect that the secularized citizens play their part in the endeavors to translate relevant contributions from the religious language into a language that is accessible to the public as a whole. (Habermas and Ratzinger, 2006, 51-2) ${ }^{19}$

This demand of "translation" for a rationally mediated peace is looking for very much needed elements of a substantial content of that peace (Steinmann, Scherer, and Ulrich, 1998, 221-39). The question is, however, if the Christian ethos is really translatable without a substantial loss of its substantial meaning. Have we to listen, at this point, to the warning of Engelhardt?

The value-rich perspective of the liberal cosmopolitan ethic is affirmed as the morally neutral perspective from which health care professionals should relate with patients. If their moral concerns cannot be translated into considerations of social democratic morality, these commitments are to remain private in the sense of excluded not only from public expression, but also from guiding even consensual actions in professional roles that are contrary to the requirements of social democratic morality.

The more professional integrity and conduct are brought within the control of a content-rich ideal of secular public reason, the more suspect the open expression of traditional Christian belief and commitments will be.

A liberal cosmopolitan ethos will require the peaceable assimilation as far as is possible of all deviant moral perspectives to its own understanding. (Engelhardt, 2000, 378)

This diagnosis is about the dynamics of assimilation. But is not there a hope that good works and their witness, instead of being absorbed by the logic of a "cosmopolitan" ethic, may reversely absorb or substitute other practices (cf. Lindbeck, 1984)? Would this not be a "rational" contribution to the common "world?" "Good works," as they explore God's will, may get into conflicts with that "world time" to which Christians should not accommodate (Rom 12:2). The consequences here may also-as Engelhardt discusses it in terms of the professional physician-touch the public justification of those professionals, who do their "good work" also according to their professional ethos, but the very point of responsibility the physician has to reflect on is not to be confined to the demands of justification or legitimacy in its given conditions. There is instead an always-present tension between various developments within medical care to the professional "ethos" with its very own grammar-for example, its consequent focus on therapy in distinction 
to any other services and products. It remains significant for the medical profession not to adjust to these external expectations. This is a vast field of conflict and contradiction as Engelhardt describes it. This field is de facto there, and there is a need for political and institutional solutions at least in order to maintain the tension between professional ethos and various positions of medical ethics and to guarantee at least a common-even if controversial"world," a "world" in need of witnessing a different ethos.

Equivalent to "good works" are institutions. Engelhardt also points to different institutions in accordance with Christian ethics. There are no constitutional barriers so far for such institutions like different hospitals, universities, schools, and also institutions, which preserve the medical ethos in its own grammar. The state, however, has not only to grant them permission. The state-as it was (in Germany) discussed by Ernst-Wolfgang Böckenförde, Habermas, and others-is in its own power positively limited and contoured insofar as it depends on these (institutionalized) counterparts preserving conditions of the civic society. The legal system can never ensure the vital and complex ground for a substantial peaceful_civic_-living together, as it was pointedly articulated by Böckenförde:

The liberal secular state lives on premises that it cannot itself guarantee. On the one hand, it can subsist only if the freedom it consents to its citizens is regulated from within, inside the moral substance of individuals and of a homogeneous society. On the other hand, it is not able to guarantee these forces of inner regulation by itself without renouncing its liberalism. (Böckenförde, 1976, 60; cf. Habermas and Ratzinger, 2006)

Any political community depends on that sphere of "good works," which are not considered to be "private" but to be constitutive as the indispensable context for a substantial public sphere.

\section{THE GOOD WORK OF UNDERSTANDING AND JUDGING: THE NOETIC TASK FOR A COMMON WORLD}

Within this context of coexistence there still remains, as we have already discussed, the political task of explicitly disclosing the "common world." This has to be realized, as Hannah Arendt (1989) has described it, by the practice of judging. We cannot avoid judging when we try to live together, and we have of course to share judgments. Judging discloses distinctions on what is real. Judging, bound to institutions, is the basic practice constituting the public sphere. There we find certain "ways of judgment" (O'Donovan, 2005). ${ }^{20}$ Outside these (institutionalized) "ways of judgment" articulating a "common world" may be a more or less peaceful, liberal, and tolerant "society," but this culturally given condition is not sufficient for a political coexistence-as it has been discussed in terms of the range and limits of practical reason-especially if we take into account that any 
element of our "human condition," as for example elements of our bodily life_-"birth," "death," "bodily suffering," "health"- determine extensively our living together. The question is again about the substance and dimensions of that "common world" if we see it within the perspective of the conditio bumana as it is determined by God's story with the world and us human beings-the story which includes resurrection and the reconciliation of the world (cosmos).

All this also opens up epistemological and hermeneutical cooperation with biosciences insofar as they share the task of disclosing the conditio bumana in its content-full givenness and appearance in a cosmic perspective. Biosciences cannot be interested in imposing a certain rational "grasp" on what we may call "nature" or "human nature." It may not be surprising that the perspective of different epistemologies and different ways of understanding attract bioscientists.

We should ask—related to Engelhardt's reminder of the noetic implications of the Christian witness-how we may describe that noetic task again as a practice which communicates that articulated and disclosed world to any other common "world" as the very common world promisingly addressed to us human beings. That practice may be seen given with the practice of judging. Judging is basically mediated by distinctions recognized as disclosing that common world on these frontlines where God's story meets this "world." Judgments within the Christian ethos follow a theological grammar given with God's story, as the distinction between God and "gods," between God and human beings (cf. Habermas, 2003), between hope and desire, between advent and future, and numerous other similar fundamental distinctions.

The practice of judging again has to be seen as a good work addressed to the public opinion and its very own patterns and languages-and this is the way of a "faith seeking understanding." Faith in its very content has "to seek understanding" - that is, to articulate and to explore its own knowledge-a "noetic" faith as Paul has indicated (Rom 12:2), different from a "faith" confined to a rational exposition. "Understanding" is not a practice of rational (self-) assurance or (self-) justification, but exploration and witness of the content of faith as it is addressed to the world (Hauerwas, 2001). (This, then, may again be called "translation."22) "Faith seeking understanding," however, has been conceived in at least two different ways-and this again is significant for its eschatological meaning (Ulrich, 2006). On the one hand, it has been read as "faith seeking understanding" in order to comprehend the content of faith according to rational evidence. A categorically different reading of "faith seeking understanding" sees "understanding" not as the procedure of assuring faith within our common "world," but as exploring, according to Paul's promising reminder (Rom 12:2), God's will—that is, what God's story with His world and with us human beings is about. This exploration would be equivalent to Jesus's prayer in Gethsemane: "My Father, if this 
cannot pass unless I drink it, your will be done" (Mt 26:42). Jesus was ready to explore His father's will by letting Him realize His will according to His story with His people.

Here we may listen to Anselm's fides quaerens intellectum according to the reading of Karl Barth. Barth notes:

From the whole tenor of his (sc. Anselm's) treatment of the problem as we have seen it up till now, it is his concern to meditate upon a particular article of the Christian Credo by itself, that is to investigate the meaning of what it contains that he may place it in its relation to all the other articles or to the one next to it, comparing and connecting it with them and allowing them to illumine it. All this he does with the intention of himself conceiving by reflection the hidden law of the object of faith about which this article speaks, that thereby he may show it forth and so be able to know the thing believed: the noetic ratio becomes the discovery of the ontic ratio in so far as it follows after it; in which case the remaining articles of the Credo point the way along which the ontic precedes the noetic ratio, along which the noetic ratio has to follow to discover it. (Barth, 1960, 53)

The "noetic" ratio as it is described here-the understanding (intelligere)follows the "ontic" ratio; it follows the very reality given with God's story. This noetic ratio follows God's story and reflects its logic given with its content. This can be seen to be close to Engelhardt's notion of a "noetic knowledge" distinct and opposite to any exclusively rational conceived reality. The affinity is given because the "noetic knowledge" is bound to God's own reality as it appears in His story.

\section{A WITNESSED WORLD (COSMOS) TO THE "WORLD"}

Engelhardt's genealogy follows certain judgments about the history of Christianity and about a "common world." Is there a hope that God's world as it appears in God's reconciliation with the world (cosmos) through Jesus Christ will become really present within this "world time"?

We read in Paul:

All this is from God, who reconciled us to himself through Christ, and has given us the ministry of reconciliation; that is, in Christ God was reconciling the world (cosmos) to himself, not counting their trespasses against them, and entrusting the message of reconciliation to us. So we are ambassadors for Christ, since God is making his appeal through us; we entreat you on behalf of Christ, be reconciled to God. (1 Cor 5:18-20)

Christians have according to this message to follow the "logos of reconciliation." This reconciliation includes the cosmos. So we read also in Paul:

For the creation was subjected to futility, not of its own will but by the will of the one who subjected it, in hope that the creation itself will be set free from its bondage to decay and will obtain the freedom of the glory of the children of God. (Rom 8:20-21) 
When we follow Paul at this point, we may ask how the "secular world," in its relation to Christian worship, or how any "world" to be addressed, appears within the story of God's reconciled world (cosmos). Which "world" are we talking about? On the one hand, it is-according to Paul-the "present world time" (in the Greek aion, in the Latin saeculum, usually translated "world") whose patterns Christians should not adopt (Rom 12:2). Therefore, Christians should also not assimilate to a Christianity that is "conformed" to this "world time" (aion). But there has been initiated a new reconciled world, a new cosmos within God's story and its new time, as affirmed in Jesus Christ. Any understanding has to follow this promise, the logos addressed to this "world time." Christians have to witness God's reconciliation. Any judgments have to be judgments of the "ambassadors for Christ," the witnesses of God's story. So we read with John Howard Yoder:

To know the Lamb who was slain was worthy to receive power not only enables his disciples to face martyrdom when they must; it also encourages them to go about their daily crafts and trades, to do their duties as parents and neighbors, without being driven by cosmic doubt. Even before the broken world can be made whole in the Second Coming, the witnesses to the first Coming - through the very fact that they proclaim Christ above the powers, the Son above the angels-are enabled to go on proleptically in the redemption of creation. Only this evangelical Christology can found a truly transformationist approach to culture. (Yoder, 1984, 61)

Is this a "transformationist approach to culture"? Bonhoeffer-as we have mentioned-has particularly emphasized this disposition of Christian witness to the present world. So we read in his Ethics:

The New Testament is concerned solely with the manner in which the reality of Christ assumes reality in the present world, which it has already encompassed, seized and possessed. There are not two spheres, standing side by side, competing with each other and attacking each other's frontiers. If that were so, this frontier dispute would always be the decisive problem of history. But the whole reality of the world is already drawn in into Christ and bound together in Him, and the movement of history consists solely in divergence and convergence in relation to this center. (Bonhoeffer, 1995, 195)

The story of the reconciled world (cosmos) has to be witnessed to any "world" or "world time." This witness is about God's story with His world, whatever the "history" of this "world time" may be. There is the logos of an already reconciled world (cosmos), where Christians and non-Christians are addressed to live in, not according to a "world time," which will disappear.

\section{HOW THE NEW WORLD BECOMES PRESENT: THE ENCOUNTER OF WORSHIP AND BIOETHICS}

The very question for any ethical reflection and judgment is how it lets appear the new world as included in God's story. If "understanding" means "exploring the new world" within this "world time" we have to look for its messianic adventus. Engelhardt is right in this crucial point, that Christian 
faith does have its real form as worship. This worship is the explorative witness of God's world to the "world."

So we read also in Paul:

I appeal to you therefore, brothers and sisters, by the mercies of God, to present your bodies as a living sacrifice, holy and acceptable to God, which is your spiritual worship. (Rom 12:1)

"Spiritual" is here-according to the New Revised Standard Version-the translation of logike, which is translated in other versions into "reasonable." Both translations have to be questioned. It is better to read "in accordance to the logos, the Word." Most important is that this worship consists of the sacrifice of the somata, which may also be translated into "lives" and "bodily existence." People of this worship let their bodily lives be absorbed by this logike worship. There is no demand of a somehow given morality, but this living bodily ethos of a worshipping community (cf. Yoder, 2001).

Essential aspects of the Christian ethos in the New Testament concur obviously with Engelhardt's reminder of the Christian worship. That worship includes the Christian ethos. ${ }^{23}$ We may follow here again Yoder's decisive point that there is a kind of mediation, a "bridging-over" ... from the faith community to the other social structures. This kind of 'mediation' is not a mental or verbal operation of translation or conceptual bridging, but rather the concrete historical presence, among their neighbors, of believers who for Jesus' sake do ordinary social things differently. They fraternize trans-ethnically; they share their bread; they forgive one another. These activities are visible; they are not opaque rituals. They lend themselves to being observed, imitated, and extrapolated. (Yoder, 2001, 75)

This is the witness of an ethos, of practices and good works. John Howard Yoder described the Christian worship, according to the New Testament, as a context of certain practices witnessing to the "world" a different way of life according to a different world-including practices which perform a Christian way of "body politics" and affect the "world" in a way that it becomes obsolete: forgiving, baptizing, breaking bread, practices according to "a new mode of group relationships," practices of listening and teaching according to the "unity in Christ" (Yoder, 2001). The Christian ethos described that way is an ethos of creaturely life, an ethos of the new creation as it appears within the present world time. Creaturely life, the life within God's story, is a living with God, with God's cooperation and the Spirit's transformation. Christian witness is about corresponding stories of this living within God's story. Transformation (Rom 12:2) is regarding most significantly the bodily given life form (morphe). This means to become "holy." To be "holy" means to live within God's story, receiving and suffering God's very own will (cf. Brock and Brock, 2007, 29-43). The witness of that holiness may be communicated in contrast to quite different ways of thinking and arguing. This kind of a story exposes a "faith seeking understanding" by exploring God's will and continuation of His story. 
Christian worship in its whole range and real focus, including genuine Christian practices and good works, signifies what is specifically Christian in relation to "bioethics." "Bioethics" appears-as Tristram Engelhardt has convincingly brought onto the agenda-as the very focus of the Christian witness to the world, because it touches paradigmatically the conditio bumana as it is determined by God's story with His creatures, fulfilled in Jesus Christ. On the agenda are not "worldviews," "anthropologies," or "histories," but the witness of God's story with the world. Christian witness concerns pivotally bioethics, because God's story encompasses the phenomena of "body," "soul," "understanding," "mind," and "spirit." Any distinction between "body" and "mind," "body" and "soul," "body" and "spirit" would not conform to God's story in Jesus Christ focusing on healing, bodily resurrection, bodily communication, body politics. The human "body" (soma) is involved in this story. The story is about God's creatures in their bodily existence. This is not because of an anthropological notion of "wholeness" or "unity of body and soul, body and spirit," but because of a human existence within the context of God's story, because of God's realization of bodily life in Jesus Christ; therefore, the phenomena of human life will be seen in a different logic. ${ }^{24}$

The growing awareness of the phenomenon of "biopolitics" - induced pivotally by Michel Foucault (2008)—is focused on the increasing governance on the human body within the wider context of body- and biotechniques in many spheres of human life. With what critical approach, with what perspective is Christian ethics or "bioethics" involved in that debate? The critical approach induced by Engelhardt concentrates on the difference between any rationalized grasp of the body and human life and a categorically different Christian notion of human bodily existence in its determination by the real Christian worship. Corinna Delkeskamp-Hayes remarks:

In reconnecting our contemporary reflections in moral theory and ontology with the moral and metaphysical commitments that lie at the roots of Western culture, Engelhardt re-opens the question concerning man's place in the cosmos. He thus secures, once again, the ground on which one could even ask the question whether or not one should pursue that genuinely (non-reduced) Christian quest for ultimate Truth into which Engelhardt invites his readers. (Delkeskamp-Hayes, 2010, 23-69, 59)

The question here, in this essay, was: What is to be recognized as the "ground" for any notion of the conditio bumana as it becomes urgently provoked within the context of bioethics, its reflection on biotechniques and biopolitics? Is there any other ground for a real understanding of the conditio bumana, a ground independent from that "reality" (Bonhoeffer) determined by God's story in Jesus Christ? That ground cannot be adequately replaced by a political context, realized in a howsoever-generated moral consensus. However, if there is no hope for a legal system representing this common ground and an equivalent consensus, is not there still not only the demand for any action to be justified to 
others, but the message of a content-full ethos (also in a legal form [cf. Williams, 2012]) addressed to our political living together? Is not there at least a "good work" of witnessing that Christian ethos about the range of this worship and its significance for the world as it has to be addressed as God's world-addressed with the message of God's story? In fact, beyond that worship there would be no message, but only an affirmation of a Christian view or position, different to others. Engelhardt's reminder of Christian worship opens up the real question for the task of Christian ethics as it becomes paradigmatically urgent in the vast field of bioethics. Bioethics is the focus of this task insofar as Christian ethics is not rooted in "ideas," "worldviews," or "anthropologies," but explores God's story with His people and the world, the transfiguration of human bodily life, its "holiness," including the renewal of human understanding.

\section{CONCLUSION}

In agreement with Tristram Engelhardt that it is impossible to defend that any secular bioethics could carry the core insights of an explicitly Christian bioethics, I have suggested that the form in which he presents this criticism nevertheless rests on concepts such as "reason" and "culture," which remain within the secular logic that is the target of his critique. This critical engagement meets in the problem of epistemology: is there a "seam" between Christian and secular/general epistemologies? Close attention to the practical rationality in which techniques of genetic alteration of the human genome are embedded suggest why the secular/general rationality of modern medicine must in fact take its orientation from some extrascientific rationality.

The Reformation traditions point us to what is, theologically speaking, the most important difference between the rationality of Christian faith and secular/general rationality: secular rationality seeks to establish the conditions for "justified" or "meaningful" action. Human beings must conform to the rules set out by this rationality.

By the properly theological account, human good works rest on the affirmation that God is the one who does justice and makes meaning. This is to understand good human action as those actions which serve God's own faithfulness and justice-making. As they negotiate the boundary between these two rationalities (medicine, operating within the orbit of secular/general rationality) Christians engage in a political negotiation with the world. Upholding the valid existence of secular rationality, they nevertheless embody an ethos that constantly negotiates the boundary of this rationality in enacting and thus witnessing to a peaceable living within God's will and acts.

To ask about the hope that orients our action in the bioethical sphere, we are exploring the boundary between these two rationalities with their different epistemologies. The differences these two epistemologies make are amply displayed in the ways we approach death, dying, and suffering. Like Engelhardt, I have explained why God's story, rather than the story of 
"history" or "progress", must determine a truly Christian assessment of these moments in human beings' lives.

Engelhardt is also correct in affirming that modern political philosophies that rest their account of justice on the idea of an "overlapping consensus" are insufficient frameworks for reaching common public judgments in the context of ethically diverse and fragmented modern societies. But again I have raised the question of whether Engelhardt has rested content too early in his criticisms of modern liberal politics in embracing an empty procedural account of the justice that can be achieved by the state. Cannot insights and practical trajectories growing from the ethos of the witnessing community lend some ethical content to modern governance?

I have proposed that this is the "good work" of the Christian political community: to foster "bonds of peace" in modern states, which suggests that debates about policies around euthanasia, reproductive cloning, and eugenics are especially apt arenas for this witness. The solution to the problem of the integrity of the Christian medical professional is therefore not, as Engelhardt proposes, to demand a morally content-empty public domain, but to insist that the good works of Christians, including those of medical practitioners, can also be affirmed as contexts in which God's making of justice and peace can invade, overturn, and even absorb all sorts of contentrich practices and ideologies. No liberal political system can survive if it does not, in fact, presume its rejuvenation by such generative practices. This line of reasoning returns us to the problem of epistemology.

It is through concrete judgments that the knowing that is bound to God's story with humans enters the public story. Christians do not shape society by claiming to discursively establish the truth or offer a foundation for all other knowledge, but by articulating judgments in practical domains which can be embraced by those who deny the ontology that provides the point of orientation of the Christian ethos. It is in this way that Christian witness to God's rule is concretized in the life of mixed societies. Here I do agree with Engelhardt's crucial insistence that the "new world" of God's works emerges most determinatively in Christian worship. As we "give over" our bodies to the "body politic" of the church, changes happen that challenge and reshape the contrasting ethos of the societies in which Christians live.

\section{NOTES}

1. I have to give many thanks to Brian Brock, who helped me, most insightfully, to bring out my argument.

2. The following essay is in many ways in agreement with McKenny (1997).

3. For that general argument, see: Habermas (2003) and Habermas (2008).

4. By "Christian" in this paper I refer mainly to the Reformed Christian tradition, but also mean to include any other Christian traditions, such as the Roman Catholic tradition or any of the Christian Orthodox traditions insofar as there can be a consensus presupposed. 
5. One might refer especially to Hans S. Reinders's most convincing critique of Engelhardt's philosophical "Bioethics" showing that "secular morality" is "much richer than liberal morality allows us to acknowledge" (Reinders, 2000, 55). Reinders's critical strategy concerning Engelhardt's philosophical bioethics may be seen parallel to my attempt to show how secular morality, regardless of its richer content, needs nevertheless the witness of Christian bioethics and a corresponding ethos as Engelhardt notes in his Foundations of Christian Bioethics, published in the same year as Hans Reinders's critique. One might ask to what extent the given experience of a more content-full morality (including a given transformation of understanding), as Reinders describes it, has still to be encountered by that conversion to Christian bioethics and its very own epistemology.

6. The most elaborated contribution to the story concept-not least within medical ethics-is to be found in Dietrich Ritschl's work. For a summary, see Ritschl (2005, 78-91).

7. All quotes from Scripture are from the NSRV, unless otherwise indicated.

8. See Engelhardt's critical remarks on Rom 12:2: "The term nous should be taken as nothing other than a synonym for the heart of which Christ and St. Paul speak, as well as certain uses of understanding or mind, as when St. Paul enjoins us to be transformed by the renewal of our minds (nous/Rom 12:2). The traditional Christian account of knowledge is that the nous is the perceptive ability of which the Gospel proclaims, 'Blessed are the pure in heart [kardia], for they shall see God' (Matt 5:8). This invocation of heart identifies the central faculty of understanding, which when opened and oriented to God transforms us so that we are restored by grace" (Engelhardt, 2000, 168). There are, however, good reasons to read "nous" as an equivalent to the Hebrew word for "understanding," e.g., in Psalm 82.

9. For the meaning of "secular" see, e.g., Williams (2012).

10. For a profound discussion with Habermas, see Kampowski (2013, 156-7).

11. For this fundamental approach to a theological way to explore the conditio bumana, see especially Sauter (2011).

12. For critical reflections on the notion of "culture" as a static entity, see Williams (2012).

13. See Habermas's commentary. He translates "good life" for the German richtiges Leben.

14. "Es gibt kein richtiges Leben im falschen" (Adorno, 1994, 42).

15. See also the debate in Engelhardt (2012).

16. For this description of judging, see Arendt (1989).

17. We could here refer on various points to Nigel Biggar's description of a Christian "behaving in public" in discussion with different theological positions and approaches. We could relate especially to Biggar's notion of a "narrative integrity." See Biggar (2011).

18. For a most impressive documentation and analysis, see Higginson (2012).

19. See also Habermas's discussion with Charles Taylor in Butler et al. (2011).

20. See also Ulrich $(2015,179-95)$.

21. This is to be seen in contradiction to a "modernity," which pretends to grasp the world by distinctions, yet produces instead hybrids. For that argument, see Latour (1993).

22. For a different notion of "translation" see Yoder $(2001,74 \mathrm{f})$.

23. For a further unfolding, see especially Wannenwetsch (2004).

24. For a deeper theological analysis, see Wannenwetsch (2013).

\section{REFERENCES}

Adorno, T. W. 1994. Minima Moralia: Reflexionen aus dem beschädigten Leben. Frankfurt/ Main, Germany: Suhrkamp.

Arendt, H. 1989. Lectures on Kant's Political Philosophy. Chicago: University of Chicago Press. Barth, K. 1960. Anselm: Fides Quaerens Intellectum: Anselm's Proof of the Existence of God in the Context of his Theological Scheme. London: SCM Press.

Benedict XVI. 2006, September 12. Faith, reason and the university: Memories and reflections. Lecture. Meeting With the Representatives of Science [On-line]. http://w2.vatican.va/content/benedict-xvi/en/speeches/2006/september/documents/hf_ben-xvi_spe_20060912_ university-regensburg.html. 
Biggar, N. 2011. Behaving in Public: How to do Christian Ethics. Grand Rapids, MI: W.B. Eerdmans Pub. Co.

Böckenförde, E.-W. 1976. Staat, Gesellschaft, Freiheit: Studien zur Staatstheorie und zum Verfassungsrecht. Frankfurt/Main, Germany: Suhrkamp.

Bonhoeffer, D. 1995. Ethics. New York: Touchstone.

Brock, B., and S. Brock. 2007. Being disabled in the new world of genetic testing. A snapshot of shifting landscapes. In Theology, Disability, And the New Genetics: Why Science Needs the Church, eds. J. Swinton and B. Brock, 29-43. London: T\&T Clark.

Butler, J., J. Habermas, C. Taylor, and C. West. 2011. The Power of Religion in the Public Sphere, eds. E. Mendieta and J. VanAntwerpen. New York: Columbia University Press.

Dabrock, P. 2010. Drawing distinctions responsibly and concretely: A European Protestant perspective on foundational theological bioethics. Christian Bioethics 16: 128-57.

Delkeskamp-Hayes, C. 2010. Morality in a post-modern, post-Christian world. Engelhardt's diagnosis and therapy. In At The Roots of Christian Bioethics: Critical Essays on the Thought of H. Tristram Engelhardt, Jr., eds. A. S. Iltis and M. J. Cherry, 23-69. Salem, MA: Scrivener Press.

Engelhardt, H. T., Jr. 1994a. Bioethics in the post-modern world. Belief in secularity. In Duties to Others, eds. C. S. Campbell and B. A. Lustig, 235-45. Dordrecht: Kluwer Academic. - 1994b. Sittlichkeit and post-modernity. An Hegelian reconsideration of the state.

In Hegel Reconsidered: Beyond Metaphysics and the Authoritarian State, eds. H. T. Engelhardt and T. Pinkard, 211-24. Dordrecht: Kluwer Academic.

- 2000. The Foundations of Christian Bioethics. Lisse, Netherlands: Swets \& Zeitlinger. 2010. Christian medical moral theology (alias bioethics) at the beginning of the twenty-first century: Some critical reflections. Christian Bioethics 16: 117-27.

- ed. 2012. Bioethics Critically Reconsidered: Having Second Thoughts. Dordrecht: Springer.

Forst, R. 2007. Das Recht auf Rechtfertigung. Elemente einer konstruktivistischen Theorie der Gerechtigkeit. Frankfurt/Main, Germany: Suhrkamp.

Foucault, M. 2008. The Birth of Biopolitics: Lectures at the Collège de France, 1978-79, ed. Michel Senellart, trans. G. Burchell. Basingstoke: Palgrave Macmillan.

Frewer, A., F. Bruns, and W. Rascher, eds. 2010. Hoffnung und Verantwortung Herausforderungen für die Medizin. Würzburg: Königshausen \& Neumann.

Habermas, J. 2003. The Future of Human Nature. Cambridge, UK: Polity. 2008. Between Naturalism and Religion: Philosophical Essays. Cambridge, UK: Polity Press.

2011. "Reasonable" versus "true," or the morality of worldviews. In Habermas and Rawls: Disputing the Political, eds. J. G. Finlayson and F. Freyenhagen, 92-113. Oxford: Taylor \& Francis.

Habermas, J., and Ratzinger, J. 2006. Dialectics of Secularization: On Reason and Religion. San Francisco: Ignatius Press.

Hauerwas, S. 1997. Not all peace is peace. Why Christians cannot make peace with Engelhardt's peace. In Reading Engelhardt. Essays on the Thought of H. Tristram Engelhardt, Jr., eds. B. Minogue, G. Palmer-Fernández, and J. E. Reagan, 31-44. Dodrecht: Kluwer.

- 2001. With The Grain of the Universe: The Church's Witness and Natural Theology: Being the Gifford Lectures Delivered at the University of St. Andrews in 2001. Grand Rapids, MI: Brazos Press.

Higginson, R. 2012. Faith, Hope \& the Global Economy: A Power for Good. Downers Grove, IL: Inter-Varsity Press.

Jonas, H. 2001. The Genesis of Values. Chicago: University of Chicago Press. 
2013. The Sacredness of the Person: A New Genealogy of Human Rights. Washington, DC: Georgetown University Press.

Kampowski, S. 2013. A Greater Freedom: Biotechnology, Love, and Human Destiny (In Dialogue with Hans Jonas and Jürgen Habermas). Eugene, OR: Pickwick.

Latour, B. 1993. We Have Never Been Modern. Cambridge, MA: Harvard University Press.

Lindbeck, G. A. 1984. The Nature of Doctrine: Religion and Theology in a Postliberal Age. Philadelphia: Westminster Press.

Löwith, K. 1950. Meaning in History. Chicago: University of Chicago Press.

1966. Nature, history and existentialism. In Nature, History and Existentialism, and Other Essays in the Philosophy of History, ed. A. Levison, 17-29. Evanston: Northwestern University Press.

MacIntyre, A. C. 1990. Three Rival Versions of Moral Enquiry: Encyclopaedia, Genealogy, and Tradition: Being Gifford Lectures Delivered in the University of Edinburgh in 1988. Notre Dame, IN: University of Notre Dame Press.

McKenny, G. 1997. To Relieve the Human Condition: Bioethics, Technology, and the Body. Albany, NY: State University of New York Press.

McKenny, G., and M. J. Cherry. 2010. Desire for the transcendent: Engelhardt and Christian ethics. In At The Roots of Christian Bioethics: Critical Essays on the Thought of H. Tristram Engelhardt, Jr., ed. A. S. Iltis, 107-33. Salem, MA: Scrivener Press.

O'Donovan, O. 2005. The Ways of Judgment: The Bampton Lectures, 2003. Grand Rapids, MI: Wm. B. Eerdmans.

Rawls, J. 2011. Political liberalism: Reply to Habermas. In Habermas and Rawls: Disputing the Political, eds. J. G. Finlayson and F. Freyenhagen, 46-91. Oxford: Taylor \& Francis.

Reinders, H. S. 2000. The Future of the Disabled in Liberal Society: An Ethical Analysis. Notre Dame, IN: University of Notre Dame Press.

Ritschl, D. 2005. Nachgedanken zum 'Story'-Konzept. Die Koagulation Wiedererzählter 'Stories' auf dem Weg zu differierenden theologischen Lehren. Theologische Zeitschrift 61: 78-91.

Sauter, G. 2011. Das verborgene Leben: eine theologische Anthropologie. München, Germany: Gütersloher Verlagshaus.

Steinmann, H., A. G. Scherer, and H. G. Ulrich. 1998. An den Grenzen der Verständigung. Oder: Was heißt es, den anderen einzubeziehen? In Zwischen Universalismus und Relativismus: Philosophische Grundlagenprobleme des interkulturellen Managements, 221-39. Frankfurt/Main, Germany: Suhrkamp.

Taylor, C. 2007. A Secular Age. Cambridge, MA: Harvard University Press.

Ulrich, H. G., and B. Brock. 2006. Fides quaerens intellectum: Reflections towards an explorative theology. International Journal of Systematic Theology 8: 42-54.

Ulrich, H. G. 2015. The ways of discernment. In The Authority of the Gospel: Explorations in Moral and Political Theology in Honor of Oliver O'Donovan, eds. R. Song and B. Waters, 179-95. Grand Rapids, MI: Eerdmans.

Wannenwetsch, B. 2004. Political Worship: Ethics for Christian Citizens. Oxford: Oxford University Press.

_ 2013. Owning our bodies? The politics of self-possession and the body of Christ (Hobbes, Locke and Paul). Studies in Christian Ethics 26: 50-65.

Williams, R. 2012. Faith in the Public Square. London: Bloomsbury.

Yoder, J. H. 1984. The Priestly Kingdom: Social Ethics As Gospel. Notre Dame, IN: University of Notre Dame Press.

2001. Body Politics: Five Practices of the Christian Community Before the Watching World. Scottdale, PA: Herald Press. 